\title{
MERETAS URGENSI AUDIT KINERJA DALAM MENCIPTAKAN AKUNTABILITAS KINERJA INSTANSI PEMERINTAH KOTA/KABUPATEN
}

\author{
Sugimin \\ Auditor Utama Inspektorat Kabupaten Sragen \\ sugimin1704@gmail.com
}

\begin{abstract}
This article explains the urgency of an audits performance (value for money audits) in creating of performance accountability at cityor district government instance. This study was conducted by literature study with reference to a number of previous study and related regulations. The results of the study indicate that performance is a formal evaluation instrument for the government program. It helps to increase the public accountability by providing information concerning the government performance that may not be accessible to the public. The understanding of this concept and its implementation will enable to achieve optimal accountability for the public sector. It is concerned about performance audits centered on economic achievement, efficiency, and effectiveness depend on the existence of regulation, planning, assessment, authorization and control over the use of its resources. It is the responsibility of the public policy makers to establish the arrangements and to ensure that they are functioning appropriately. The responsibility of the internal auditor is to independently verify that execution of activities by policymakers have complied with the basic standards.
\end{abstract}

Keywords: Audit Performance, Government Performance, Public Accountability

\begin{abstract}
ABSTRAK
Artikel ini menjelaskan urgensi kinerja audit (nilai untuk audit uang) dalam menciptakan akuntabilitas kinerja pada contoh pemerintah kota atau kabupaten. Penelitian ini dilakukan oleh studi literatur dengan mengacu pada sejumlah penelitian sebelumnya dan peraturan terkait. Hasil penelitian menunjukkan bahwa kinerja merupakan instrumen evaluasi formal untuk program pemerintah. Ini membantu meningkatkan akuntabilitas publik dengan memberikan informasi mengenai kinerja pemerintah yang mungkin tidak dapat diakses oleh publik. Pemahaman konsep ini dan implementasinya akan memungkinkan untuk mencapai akuntabilitas yang optimal untuk sektor publik. Hal ini prihatin dengan audit kinerja yang berpusat pada pencapaian ekonomi, efisiensi, dan efektivitas tergantung pada keberadaan regulasi, perencanaan, penilaian, otorisasi dan kontrol atas penggunaan sumber dayanya. Adalah tanggung jawab pembuat kebijakan publik untuk menetapkan pengaturan dan untuk memastikan bahwa mereka berfungsi dengan tepat. Tanggung jawab auditor internal adalah untuk secara independen memverifikasi bahwa pelaksanaan kegiatan oleh pembuat kebijakan telah memenuhi standar dasar.
\end{abstract}

Kata Kunci: Kinerja Audit, Kinerja Pemerintah, Akuntabilitas Publik

\section{PENDAHULUAN}

Krisis berkepanjangan pada beberapa dekade yang lalu terasa getir karena menimbulkan keterpurukan bagi bangsa dan rakyat Indonesia. Namun di sisi lain terdapat hikmah positif yang merupakan blessing in disguised adalah timbulnya ide dan 
pemikiran dasar yang menumbuhkan "reformasi total" di dalam segala aspek kehidupan berbangsa dan bernegara. ${ }^{1}$ Orientasi tujuan reformasi total ini adalah mewujudkan civil society dalam kehidupan bermasyarakat, berpemerintahan, dan bernegara yang memiliki nilai-nilai good governance yang memunculkan nilai demokrasi dan sikap keterbukaan, kejujuran, keadilan, berorientasi kepada kepentingan rakyat, serta bertanggungjawab kepada rakyat.

Reformasi menggeser paradigma dari sistem pemerintahan yang sentralistik ke arah sistem pemerintahan yang desentralistik dalam wujud otonomi daerah. Salah satu tolok ukur keberhasilan otonomi daerah adalah terciptanya "good governance" dimana "good governance" memiliki banyak dimensi salah satuya adalah dimensi akuntabilitas publik. Multiplayer Effect adanya reformasi bagi pemerinatahan adalah terciptanya pemerintahan yang good governance dan terhindar dari praktik fraud. Pemerintahan yang terhindar dari praktik korupsi, kolusi dan nepotisme (KKN) merupakan indikator dari wujud tata kelola pemerintahan yang baik(good governance). Good Governance ditandai dengan tiga pilar utama yang merupakan elemen dasar saling berkaitan, yaitu partisipasi, transparansi dan akuntabilitas. ${ }^{2}$

Untuk meminimalkan terjadinya pemerintahan yang menyimpang dan tidak akuntabel diperlukan sistem akuntabilitas yang baik. Sistem akuntabilitas yang baik memerlukan adanya saluran saluran pertanggung jawaban yang tersistem secara dengan baik sehingga dapat mencegah terjadinya fraud dalam pemerintahan. Salah satu fungsi yang harus ada dalam proses akuntabilitas adalah fungsi pemeriksaaan atau auditing. Mekanisme audit merupakan sebuah mekanisme yang dapat menggerakkan makna akuntabilitas di dalam pengelolaan sektor pemerintahan, Badan Usaha Milik Negara (BUMN), atau pengelola asset negara lainnya. ${ }^{3}$

Konteks pengganggaran, fungsi pengawasan dilakukan pada setiap tahapan penganggaran mulai dari perencanaan, pelaksanaan sampai dengan tahap evaluasi. Fungsi pengawasan pada dasarnya lebih bertujuan untuk menjamin tercapainya

\footnotetext{
1Suryo Pratolo, "Value For Money Audit Suatu Instrumen Alternatif untuk Menciptakan Akuntabilitas Publik Pemerintah Daerah," Jurnal Akuntansi dan Investasi 4, no. 1 (2003): 29.

${ }^{2}$ Abdul Halim dan Syam Kusufi, Teori, Konsep, dan Aplikasi Akuntansi Sektor Publik: Dari Anggaran Hingga Laporan Keuangan Dari Pemerintah Hingga Tempat Ibadah (Jakarta: Salemba Empat, 2012), 366.

3Indra Bastian, Audit Sektor Publik (Jakarta: Visi Global Media, 2003), 151.
} 
tujuan secara optimal.Ahmad Tarigan dalam Sri Bunga Rampai Manajemen Keuangan yang diedit oleh Abdul Halim, menyatakan bahwa fungsi pemeriksaan bertujuan untuk menjamin laporan pertanggungjawaban (laporan keuangan dan kinerja) disusun sesuai dengan ketentuan yang berlaku. ${ }^{4}$ Oleh karena itu, fungsi pemeriksaan biasanya berada pada tahap evaluasi atau pertanggungjawaban anggaran.

Standar Audit menjadi sangat penting karena standar tersebut menjadi panduan dasar bagi auditor untuk mempertahankan nilai nilai etika dan memenuhi tujuan audit. Khususnya bagi auditor internal di tingkat pemerintahan kota/kabupaten, standar audit sangat membantu dalam pelaksanaan audit kinerja. Dalam perspektif internal, audit kinerja merupakan perkembangan dari audit intern (internal audit) yang kemudian berkembang lagi menjadi audit operasional (operational audit) dan selanjutnya menjadi audit manajemen (management audit). Kombinasi antara audit manajemen dan audit program inilah yang disebut sebagai audit kinerja (performance audit). Bertitik tolak dari ulasan yang telah dipaparkan kajian ini membahas secara detail mengenai audit kinerja dan berbagai yang melingkupinya secara holistic serta pembahsan yang komprehensif terkait topic yang diangkat.

\section{PEMBAHASAN}

\section{DISTINGSI PENGAWASAN DAN PEMERIKSAAN}

Secara konsepsional, pelaksanaan pemeriksaan APBN/APBD sangat berbeda dari aspek pengawasan. Istilah pemeriksaan (auditing) adalah sebuah istilah teknis professional. Oleh karena itu secara teknis professional, pemeriksaan APBN/APBD hanya dapat dilakukan oleh institusi yang memiliki wewenang dan keahlian untuk melakukan audit. Sedangkan berbagai cara yang dilakukan oleh pihak pihak lain sehubungan dengan pelaksanaan fungsi pengawasan APBN/APBD, harus dilihat semata mata sebagai bagian dari proses pengawasan. ${ }^{5}$ Pengawasan dapat dilakukan dari pihak internal dan juga eksternal. Pengawasan internal dilakukan oleh pimpinan, sedangkan pengawasan eksternal oleh lembaga legislative dan masyarakat.

\footnotetext{
${ }^{4}$ Abdul Halim, Seri Bunga Rampai Manajemen Keuangan Daerah: Akuntansi dan Pengendalian Pengelolaan Keuangan Daerah (Yogyakarta: UPP STIM YKPN, 2007), 126.

${ }^{5}$ Abdul Halim, 126.
} 
Secara operasional, antara pengawasan dan pemeriksaan memang sulit dipisahkan. Dalam rangka fungsi pengawasan oleh pimpinan misalnya, pemeriksaan selalu menyertai pengawasan. Pengawasan merupakan tindakan untuk membandingkan antara yang seharusnya terjadi atau menjamin pencapaian tujuan tertentu secara optimal. Sama halnya dengan pengawasan, membagi pemeriksaan keuangan menjadi dua jenis, yaitu pemeriksaan keuangan yang dilakukan secara internal dan eksternal.6 Pemeriksaan keuangan secara internal lembaga atau instansi tertentu yang berfungsi melakukan pemeriksaan sebagai bentuk fungsi pengawasan dari pimpinan. Misalnya Badan Pengawasan Keuangan dan Pembangunan (BPKP) yang melakukan pemeriksaan dalam lingkungan pemerintahan secara keseluruhan, yang menjalankan fungsi pengawasan dari presiden selaku kepala pemerintahan, atau inspektorat wilayah (irwil) dalam lingkungan pemerintah daerah. Sementara itu, pelaksanaan pemeriksaan keuangan secara eksternal dijalankan oleh Badan Pemeriksaan Keuangan (BPK) yang menjalankan amanat konstitusi untuk memeriksan pertanggungjawaban keuangan pemerintah terhadap DPR/DPRD dan masyarkat. Sebagai bagian dari pelaksanaan fungsi pengawasan dari pimpinan, pemeriksaan keuangan secara internal, yaitu membandingkan hasil yang seharusnya terjadi dengan yang benar benar terjadi.

Pengawasan dilakukan oleh pihak luar eksekutif (dalam hal ini DPR/DPRD dan masyarakat) lebih menekankan evaluasi terhadap seseorang pimpinan untuk memastikan bahwa pimpinan telah menjalankan tugasnya sesuai dengan amanat, sementara pengawasan secara internal lebih berupa pengendalian internal dan pengendalian manajemen, yang berada di bawah kendali (pemerinth daerah) dan dilakukan untuk memastikan strategi dijalankan dengan baik sehingga tujuan tercapai.

Pemeriksaan(audit) dilakukan oleh badan yang meiliki kompetensi dan indepensi untuk mengukur apakah kinerja oleh badan yang memiliki kompentensi dan independensi untuk mengukur apakah kinerja eksekutif sudah sesuai dengan Kriteria yang ditetapkan.7 Penguatan fungsi pengawasan dapat dilakukan melalui optimalisasi peran DPR/DPRD strategi kekuatan sebagai kekuatan penyeimbang antara eksekutif dengan masyarakat, baik secara langsung maupun tidak langsung,

${ }^{6}$ Abdul Halim, 127.

7Mardiasmo, "Pengawasan, Pegendalian, Dan Pemeriksaan Kinerja Pemerintah Daerah Dalam Pelaksanaan Otonomi Daerah," Jurnal Bisnis dan Akuntansi 3, no. 2 (2001): 445. 
dan melalui LSM serta organisasi kemasyarakatan di daerah. Perlu dipahami anggota DPR/DPRD bahwa pengawasan terhadap eksekutif adalah pengawasan terhadap pelaksanaan kebijakan yang telah digariskan, bukan pemeriksaan (audit). Pemeriksaan tetap harus dijalankan oleh badan atau lembaga yang memiliki otoritas dan keahlian professional, seperti BPK, atau Kantor Akuntan Publik (KAP) yang menjalankan fungsinya lebih pada sector swasta sehingga pada sektor public perlu ditingkatkan.

\section{LINGKUNGAN AUDIT SEKTOR PUBLIK}

Karakter audit sektor publik dapat dapat dikupas melalui artikulasi definisi frasa "sektor public". Dari berbagai kupasan seminar dan lokakarya, pemahaman sektor publik sering diartikan sebagai aturan pelengkap pemerintah yang mengakumulasikan "utang sektor publik" dan "permintaan pinjaman sektor publik" untuk tahun tertentu. Artikulasi ini merupakan dampak dari sudut pandang ekonomi dan politik yang selama ini mendominasi perdebatan sektor publik. Dari sisi kebijakan sektor publik, sektor publik dipahami sebagai tuntutan pajak, birokrasi yang berlebihan, pemerintahan yang besar, dan nasionalisasi versus privatisasi. Terlihat jelas dalam arti luas bahwa sektor publik disebut sebagai bidang yang membicarakan metode manajemen negara. Sedangan dalam arti sempit, sektor publik diartikan sebagai pembahasan pajak dan kebijakan negara.

Perbedaan sudut pandang politik, administrasi publik, sosiologi, hukum dan ekonomi sering kali mengakibatkan tumpang tindihnya batasan. Perkembangan yang ada saat ini lebih ke arah pendekatan yang dipilih, seperti: gender, politik ekonomi, kepemilikan (ekuitas), akuntabilitas, dan hak asasi. Atau dengan kata lain, pegertian cakupan sektor publik dapat disimpulkan secara longgar dan luas.

Perkembangan paradigma keperintahan di berbagai negara yang sedang dalam proses pergeseran dari ruling government menuju ke arah government dan penciptaan administrasi pemerintah yang berhasil guna, berdaya guna dan berkeadilan telah menimbulkan kesadaran bagi setiap orang, terutama aparat pemerintah untuk senantiasa tanggap akan tuntutan lingkungannya dengan berupaya memberikan pelayanan yang terbaik, transaparan dan akuntabel. ${ }^{8}$ Sejarah organisasi sektor publik sebenarnya telah dimulai sejak ribuan tahun yang lalu. Kemunculan lebih dipengaruhi

8Indra Bastian, Audit Sektor Publik (Jakarta: Salemba Empat, 2007), 51. 
$6 \mid$ Sugimin

oleh interaksi dan kekuatan social dalam masyarakat. Berdasarkan kekuatan social masyarakat yang umumnya berbentuk pemerintahan, organisasi sektor publik ini dapat diklasifikasikan dalam beberapa konsep, yaitu:

- Semangat kapitalisasi (capitalistic spirit)

- Peristiwa politik dan ekonomi (economic and politic event)

- Inovasi teknologi (technology innovation)

\section{PROSES AUDIT DALAM SEKTOR PUBLIK}

Perkembangan terbaru dari auditing di sektor publik adalah adanya audit kinerja atau juga ada yang menyebutnya valu for money audit (VFM audit). Audit kinerja sendiri merupakan perluasan dari audit keuangan dan audit kepatuhan. Sehingga, tidak terdapat perbedaan yang mendasar antara proses audit kinerja dengan proses audit keuangan. Sebelum melakukan audit, auditor terlebih dahulu harus memperoleh informasi umum organisasi guna mendapatkan pemahaman yang memadai tentang lingkungan organisasi yang diaudit, struktur organisasi, misi organisasi, proses kerja, serta system informasi dan pelaporan. Pemahaman lingkungan masing masing organisasi akan memberikan dasar untuk memperoleh penjelasan dan analisis yang lebih mendalam mengenai system pengendalian manajemen. Berdasarkan hasil analisis terhadap kelemahan dan kekuatan system pengendalian dan pemahaman mengenai keluasan (scope), validitas dan realibilitas informasi kinerja yang dihasilkan oleh entitas atau organisasi, auditor kemudian menetapkan kinerja audit dan mengembangkan ukuran ukuran kinerja yang tepat. Berdasarkan rencana kerja yang telah dibuat, auditor melakukan penaguditan, mengembangkan hasil hasil temuan audit dan membandingkan antara kinerja yang dicapai dengan criteria yang ditetapkan sebelumnya. Hasil temuan kemudian dilaporkan kepada pihak pihak yang membutuhkan disertai dengan rekomendasi yang diusulkan oleh auditor. Pada akhirnya rekomendasi rekomendasi yang diusulan oleh auditor akan ditindak lanjuti oleh pihak pihak berwenang. Proses audit keuangan secara umum dapat dikelompokkan menjadi tiga tahap utama, yaitu10:

1. Perencanaan audit

9Indra Bastian, 52.

10Mahmudi, Manajemen Kinerja Sektor Publik (Yogyakarta: UPP STIM YKPN, 2007), 194. 
2. Pekerjaan lapangan (pelaksanaan audit)

3. Pelaporan

Sedangkan pada proses audit kinerja tidak berbeda untuk tahap ke 1 sampai dengan tahap ke 3, namun ditambah dengan tahap ke 4 yaitu tahap tindak lanjut (follow up) audit. Sama halnya dengan Mardiasmoyang menyatakan bahwa struktur audit kinerja terdiri atasa tahap pengenalan dan perencanaan, tahap pengauditan, tahap pelaporan dan tahap penindaklanjutan. ${ }^{11}$ Pada tahap pengenalan dilakukan survey pendahuluan dan review system pengendalian manajemen. Pekerjaan yang dilakukan pada survey pendahuluan dan review system pengendalian manajemen bertujuan untuk menghasilkan rencana penelitian yang detail yang dapat membantu auditor dalam mengukur kinerja dan mengembangkan temuan berdasarkan perbandingan antara kinerja dan criteria yang telah ditetapkan sebelumnya.

\section{Komparasi Audit Keuangan dan Audit Kinerja}

Secara proses dan teknik pengauditan antara audit keuangan dan audit kinerja tidak ada perbedaan yang mendasar. Bahkan definisi audit kinerja dapat diturunkan dari audit keuangan. Perbedaan diantara keduanya terletak pada objek yang diaudit, focus audit, dan kriteria atau standar yang digunakan dalam melakukan audit. ${ }^{12}$ Perbandingan antara audit keuangan dan audit kinerja yaitu:

Perbandingan Audit Keuangan dan Audit Kinerja. ${ }^{13}$

\begin{tabular}{|l|l|}
\hline \multicolumn{1}{|c|}{ Audit Keuangan } & \multicolumn{1}{c|}{ Audit Kinerja } \\
\hline Objek Audit: Laporan keuangan & $\begin{array}{l}\text { Objek Audit: organisasi, program, } \\
\text { aktivitas/kegiatan, atau fungsi }\end{array}$ \\
\hline $\begin{array}{l}\text { Menguji kewajaran laporan keuangan } \\
\text { dari salah saji yang material dan } \\
\text { kesesuaianya dengan prinsip akutansi } \\
\text { berterima umum }\end{array}$ & $\begin{array}{l}\text { Menguji tingkat ekonomi, efisiensi, dan } \\
\text { efektivitas dalam penggunaan sumber } \\
\text { daya untuk mencapai tujuan }\end{array}$ \\
\hline Lebih bersifat kuantitatif-keuangan & Lebih bersifat kualitatif \\
\hline Tidak terlalu analitis & Sangat analitis \\
\hline $\begin{array}{l}\text { Tidak menggunakan indicator kinerja, } \\
\text { standar, dan target kinerja }\end{array}$ & $\begin{array}{l}\text { Membutuhkan indicator kinerja, standar, } \\
\text { dan target kinerja untuk mengukur } \\
\text { kinerja }\end{array}$ \\
\hline $\begin{array}{l}\text { Biasanya tidak mempertimbangkan } \\
\text { analisis biaya manfaat }\end{array}$ & $\begin{array}{l}\text { Biasanya mempertimbangkan cost-benefit } \\
\text { analysis }\end{array}$ \\
\hline
\end{tabular}

11Mardiasmo., Akuntansi Sektor Publik (Yogyakarta: ANDI, 2009), 197.

12Mahmudi, Manajemen Kinerja Sektor Publik, 287.

${ }^{13}$ Mahmudi, 288. 


\begin{tabular}{|l|l|}
\hline $\begin{array}{l}\text { Waktu pelaksanaan audit tertentu } \\
\text { (biasanya pada periode tertentu) }\end{array}$ & Audit bisa dilakukan sewaktu waktu \\
\hline $\begin{array}{l}\text { Audit dilakukan untuk peristiwa } \\
\text { keuangan masa lalu }\end{array}$ & $\begin{array}{l}\text { Mempertimbangkan kinerja masa lalu, } \\
\text { sekarang, dan masa mendatang }\end{array}$ \\
\hline $\begin{array}{l}\text { Tidak dimaksudkan untuk membantu } \\
\text { melakukan sumber daya secara optimal }\end{array}$ & $\begin{array}{l}\text { dimaksudkan untuk memperbaiki } \\
\text { alokasi sumber daya secara optimal dan } \\
\text { memperbaiki kinerja }\end{array}$ \\
\hline Tidak terdapat audit dan follow up audit & $\begin{array}{l}\text { Terdapat rekomendasi audit dan follow } \\
\text { up audit }\end{array}$ \\
\hline
\end{tabular}

Audit kinerja menfokuskan pemeriksaan pada tindakan tindakan dan kejadian kejadian ekonomi yang menggambarkan kinerja entitas atau funsgi yang diaudit. Audit kinerja merupakan suatu proses yang sistematis untuk memperoleh dan mengevaluasi bukti secara objektif agar dapat melakukan penilaian secara independen atas ekonomi dan efisiensi koperasi, efektivitas dalam pencapaian hasil yang diinginkan dan kepatuhan terhadap kebijakan, peraturan dan hukum yang berlaku, menentukan kesesuaian antara kinerja yang telah dicapai dengan kriteria yang telah ditetapkan sebelumnya serta mengkomunikasikan hasilnya kepada pihak pihak pengguna laporan tersebut. ${ }^{14}$

\section{Audit Kinerja (Value For Money Audit)}

Audit Kinerja atau sering dikenal dengan performance audit atau value for money audit merupakan jenis audit yang relative baru dalam organisasi sektor publik.15 Audit kinerjamerupakan perluasan dari keuangan, dalam hal tujuan dan prosedurnya. Value for Money Audit merupakan instrumen yang paling sesuai menjamin diberlakukannya pertanggungjawaban publik oleh pemerintah daerah.16Seperti kita ketahui definisi Value for Money Audit adalah suatu proses sistematis untuk memperoleh dan mengevaluasi bukti secara obyektif, agar dapat melakukan penilaian secara independen atas ekonomi dan efisiensi operasi, efektivitas dalam pencapaian hasil yang diinginkan, dan kepatuhan terhadap kebijakan, peraturan hukum yang berlaku, menentukan kesesuaian antar kinerja yang telah dicapai dengan kriteria yang telah

${ }^{14}$ R.M. Malan dkk., Performance Auditing in Local Government (Chicago, Illinois: Government Finance Offecers Association., 1984), 23.

${ }^{15}$ Mahmudi, Manajemen Kinerja Sektor Publik, 197.

16Pratolo, "Value For Money Audit Suatu Instrumen Alternatif untuk Menciptakan Akuntabilitas Publik Pemerintah Daerah," 33. 
ditetapkan sebelumnya, serta mengkomunikasikan hasilnya kepada fihak fihak pengguna laporan tersebut. ${ }^{17}$

Hal ini tentu lebih luas cakupannya dari conventional audit, dikarenakan dalam pemeriksaan yang konvensional lingkup pemeriksaannya hanya sebatas audit terhadap keuangan dan kepatuhan (financial and compliance audit). Sehingga apabila audit konvensional diimplemtasikan, rakyat tidak akan mengetahui apakah selama ini pemerintah telah benar-benar efektif dan efisien dalam menggunakan setiap rupiah uang rakyat. Padahal jika meninjau dari misi dan visi organisasi sektor publik (pemerintah daerah) adalah pelayanan publik, sehingga yang dibutuhkan publik (rakyat) adalah sejauh mana pemerintah darahnya telah melaksanakan pelayanan publik secara ekonomis, efisien, dan efektif tidak hanya sekedar kepatuhan terhadap peraturan ataupun perundang-undangan dan kewajaran laporan pertanggungjawaban pemerintah daerah. ${ }^{18}$

Menurut SPKN, yang dimaksud dengan audit kinerja adalah pemeriksaan atas pengelolaan keuangan negara yang terdiri atas audit aspek ekonomi, efisiensi dan efektivitas. Audit kinerja pada sebuah program pemerintah meliputi juga atas audit kepatuhan terhadap ketentuan perundang-undangan serta pengujian terhadap pengendalian internal.19 Audit kepatuhan adalah audit yang memverifikasi/memeriksa bahwa pengeluaran pengeluaran untuk pelayanan masyarakat telah disetujui dan telah sesuai dengan perundang-undangan peraturan. Dalam audit kepatuhan terdapat asas kepatutan selain kepatuhan. Dalam kepatuhan yang dinilai adalah ketaatan semua aktifitas sesuai dengan kebijakan, aturan, ketentuan dan undang-undang yang berlaku. Sedangkan kepatutan lebih kepada keluhuran budi pimpinan dalam mengambil keputusan. Jika melanggar kepatutan belum tentu melanggar kepatuhan.

Laporan audit merupakan unsur utama yang dapat membedakan Value For Money Audit dengan Conventional Audit. Pada audit konvensional, hasil audit adalah berupa opini auditor secara independen dan obyektif tentang kewajaran laporan

${ }^{17 R . M . ~ M a l a n ~ d k k ., ~ P e r f o r m a n c e ~ A u d i t i n g ~ i n ~ L o c a l ~ G o v e r n m e n t, ~} 21$.

${ }^{18}$ Suryo Pratolo, "Value For Money Audit Suatu Instrumen Alternatif untuk Menciptakan Akuntabilitas Publik Pemerintah Daerah," 33.

${ }^{19}$ Oktarika Ayoe Sandha dan Indra Bastian, Program Audit Kinerja Berbasis SPKN (Yogyakarta: BPFE UGM, 2008), 76. 
keuangan sesuai dengan kriteria standard yang telah ditetapkan, tanpa pemberian rekomendasi perbaikan. Sedangkan dalam Value For Money Audit tidak sekedar menyampaikan kesimpulan berdasarkan tahapan audit yang telah dilaksanakan, akan tetapi juga dilengkapi dengan rekomendasi untuk perbaikan di masa mendatang. ${ }^{20}$ Dengan dilakukannya Value for Money Audit oleh auditor professional dan independen akan dihasilkan informasi mengenai tingkat ekonomis, efisiensi, efektivitas pelayanan publik pemerintah daerah secara transparan berdasarkan pada apa yang sebenarnya terjadi tidak sekerdar pada laporan pertanggungjawaban dan laporan keuangan pemerintah daerah. ${ }^{21}$

Value for money auditmencakup audit ekonomi, efisiensi, dan efektivitas yang pada intinya merupakan perluasan dari audit keuangan terkait dengan tujuan dan prosedurnya. Pada dasarnya value for money audit dapat diturunkan dari definisi audit keuangan, sehingga pada audit keuangan dan value for money audit tidak terdapat perbedaan definisi yang tajam. Value for Money Auditlebih memfokuskan pemeriksaan pada tindakan-tindakan dan kejadian-kejadian ekonomi yang menggambarkan kinerja entitas atau fungsi yang diaudit.

Kinerja pemerintah daerah dikatan baik apabila pemerintahan yang bersangkutan mampu melaksanakan tugas-tugas dalam rangka mencapai tujuan yang telah ditetapkan sesuai dengan Standar Akuntansi Pemerintahan (SAP). Secara teknis kinerja yang baik adalah ketika administrasi dan penyediaan jasa oleh organisasi yang bersangkutan dilakukanpada tingkat ekonomis, efisien, dan efektif. Konsep-konsep tersebut saling berhubungan satu sama lain dan tidak dapat dimaknai secara terpisah atau sendiri-sendiri. Konsep ekonomi memastikan bahwa biaya input yang digunakan dalam operasional organisasi dapat diminimalkan, konsep efisien memastikan bahwa output yang maksimal dapat dicapai dengan sumber daya yang tersedia, konsep efektif berarti bahwa jasa yang disediakan dihasilkan oleh organisasi dapat melayanai kebutuhan pengguna jasa dengan tepat. ${ }^{22}$

Pada umumnya hasil Value for Money Audit menjadi dasar bagi DPRD yang bertindak sebagai wakil rakyat untuk memberi masukan dan menilai

${ }^{20}$ Mardiasmo., Akuntansi Sektor Publik, 199.

21Pratolo, "Value For Money Audit Suatu Instrumen Alternatif untuk Menciptakan Akuntabilitas Publik Pemerintah Daerah," 34.

22Mardiasmo., Akuntansi Sektor Publik, 200. 
pertanggungjawaban seorang kepala daerah dan dapat digunakan untuk memantau kinerja pemerintah daerah. Sehingga bertitik tolak dari hal tersebut diharapkan akuntabilitas publik dapat terwujud sebagaimana mestinya.

\section{Elemen Audit Kinerja}

Aduit Kinerja pada dasarnya melibatkan penelaahan terhadap aspek-aspek terkait sifat dan fungsi organisasidari sistem dan prosedur manajerialnya, ekonomi dan efisiensi dalam proses pelayanan public dan efektivitas kinerja dalam mencapai tujuan. ${ }^{23}$ Dalam memeriksa audit, akuntabilitas dan kontrol, juga mengidentifikasi tiga elemen dasar dari audit kinerjayaitu audit ekonomi, efisiensi dan efektivitas.24Pengklasifikasikan elemen-elemen ini menjadi dua tanggung jawab Manajerial untuk efisiensi dan ekonomi operasi, dan tanggung jawab manajerial untuk efektivitas. ${ }^{25}$

Kinerja suatu organisasi dinilai baik jika organisasi yang bersangkutan mampu melaksanakan tugas tugas dalam rangka mencapai tujuan yang telah ditetapkan pada standar yang tinggi dengan biaya yang rendah. Kinerja yang baik bagi suatu organisasi dicapai ketika administrasi dan penyediaan jasa oleh organisasi yang bersangkutan dilakukan pada tingkat yang ekonomis, efisien dan efketif. Konsep ekonomi, efisiensi dan efektivitas saling berhubungan satu sama lain dan tidak dapat diartika secara terpisah. Konsep ekonomi memastikan bahwa biaya input yang digunakan dalam operasional organisasi dapat diefisiensikan. Konsep efiesien memastikan bahwa output yang maksimal dapat dicapai dengan sumber daya yang tersedia. Sedangkan konsep efektif berarti bahwa jasa yang dihasilkan atau disediakan oleh organisasi dapat melayani pengguna jasa dengan tepat. Jadi audit yang dilakukan dalam audit kinerja meliputi audit ekonomi, efisiensi dan efektivitas, disebut manajemen audit. Sedangkan audit efektivitas disebut program audit.

\section{a) Audit Ekonomi}

${ }^{23}$ M. Eze Nwosu, "VALUE FOR MONEY AUDIT: AN ACCOUNTABILITY TOOL IN THE NIGERIA PUBLIC SECTOR," International Journal of Economics, Commerce and Management Vol. III, no. Issue 6 (Juni 2015): 1540.

${ }^{24}$ I.E. Johnson, Public Sector Accounting and Financial Control. (Lagos: Financial Training Nigeria, 1996), 22.

${ }^{25 K}$. Oshisami, Government Accounting and Financial Control (Ibadan: Spectrum Books Ltd, 1992), 24. 
Audit Ekonomi membutuhkan pemeriksaan mendalam tentang target yang dicapai dan sumber daya terkait yang digunakan untuk mencapai tujuan yang telah ditetapkan. Johnson menyatakan bahwa pencapaian hasil tertentu dengan pengeluaran sumber daya semestinya. ${ }^{26}$ Intinya, audit ekonomi operasi memerlukan minimisasi pengeluaran dalam proses mencapai serangkaian tujuan. Oleh karena itu, untuk mencapai hal ini, dibutuhkan tindakan untuk menghindari prosedur yang mahal dan pemborosan sumber daya.

\section{b) Audit Efisiensi}

Fokus Audit Efisiensi adalah untuk memastikan bahwa hasil terbaik dicapai dari sumber daya yang tersedia. ${ }^{27}$ Sementara Johnson mencatat bahwa efisiensi operasi adalah hubungan antara tingkat layanan yang disediakan dan sumber daya yang digunakan untuk mencapai tingkat tertentu. ${ }^{28}$ Untuk mencapai hal ini, itu berarti bahwa sumber daya perlu direncanakan dengan benar untuk, diorganisir, dimanfaatkan, dan dikendalikan.

\section{c) AuditEfektivitas Operasi}

Dalam hal ini, upaya dilakukan untuk menentukan sejauh mana target yang ditetapkan untuk program atau kegiatan benar-benar tercapai. Tujuan yang ditetapkan oleh organisasi terpenuhi dan apakah organisasi, telah mempertimbangkan alternatif lain yang mungkin menghasilkan hasil yang diinginkan dengan biaya rendah. ${ }^{29}$ Ini akan melibatkan analsisis yang lebih mendalam terhadap hasil atau manfaat yang dicapai dan program atau kegiatan untuk menentukan pencapaian mereka dari tujuan yang ditetapkan. Dalam melakukan audit kinerja, hal hal yang perlu diperhatian adalah alternatif tindakan yang dapat meminimalkan biaya, hasil yang dicapai, output tercapai dari target yang ditetapkan, hasil dapat ditingkatkan tanpa menimbulkan biaya tambahan, pengeluaran yang sepadan dengan hasil, menghilangkan proses atau prosedur yang tidak perlu, pengamanan yang memadai untuk aset yang dimiliki oleh organisasi. 30

26.E. Johnson, Public Sector Accounting and Financial Control., 72.

${ }^{27}$ E. Ene, "Value for Money Audit in the Public Sector," ICAN Student Newsletter, Desember 2000, 10.

28I.E. Johnson, Public Sector Accounting and Financial Control., 72.

${ }^{29} \mathrm{~K}$. Oshisami, Government Accounting and Financial Control, 193.

30M. Eze Nwosu, "Value For Money Audit: An Accountability Tool In The Nigeria Public Sector," 1541. 


\section{A. KESIMPULAN}

Salah satu fungsi yang harus ada dalam proses akuntabilitas publik adalah fungsi pemeriksaan atau auditing. Fungsi pemeriksaan berbeda dengan fungsi pengawasan. Secara konsepsional pelaksanaan pemeriksaan APBN/APBD sangat berbeda dari aspek pengawasan. Namun secara operasional, antara pengawasan dan pemeriksaan sulit dipisahkan. Audit yang dilakukan pada sektor publik pemerintah berbeda dengan yang dilakukan pada sektor swasta. Perbedaan tersebut disebabkan oleh adanya perbedaan latar belakang institusional dan hukum. Dimana audit sektor publik pemerintah mempunyai prosedur dan tanggung jawab yang berbeda serta peran yang lebih luas dibanding audit sektor swasta. Secara umum ada 3 jenis audit dalam audit sektor publik yaitu audit keuangan, audit kinerja, dan audit investigasi. Proses audit kinerja meliputi perencanaan audit, pekerjaan lapangan (pelaksanaan audit), pelaporan dan yang terakhir tahap tindak lanjut audit. Struktur audit kinerja terdiri atas tahap pengenalan dan perencanaan, tahap pengauditan, tahap pelaporan dan tahap penindak lanjutan. Pada tahap pengenalan dilakukan survey pendahuluan dan review sistem pengendalian manajemen. Tahap pengauditan dalam audit kinerja terdiri atas 3 elemen, yaitu telaah hasil hasil program, telaah ekonomi dan efisiensi, dan telaah kepatuhan. Tahap pelaporan merupakan tahapan yang harus dilaksanakan karena adanya tuntuntan yang tinggi dari masyarakat atas pengelolaan sumber daya publik. Tahap yang terakhir adalah tahap penindaklanjutan dimana dalam tahap ini didesain untuk memastikan atau memberikan pendapat apakah rekomendasi yang diusulkan auditor sudah diimplementasikan.

\section{REFERENSI}

Abdul Halim. Seri Bunga Rampai Manajemen Keuangan Daerah: Akuntansi dan Pengendalian Pengelolaan Keuangan Daerah. Yogyakarta: UPP STIM YKPN, 2007.

Abdul Halim, dan Syam Kusufi. Teori, Konsep, dan Aplikasi Akuntansi Sektor Publik: Dari Anggaran Hingga Laporan Keuangan Dari Pemerintah Hingga Tempat Ibadah. Jakarta: Salemba Empat, 2012. http://www.penerbitsalemba.com.

E. Ene. "Value for Money Audit in the Public Sector." ICAN Student Newsletter, Desember 2000.

I.E. Johnson. Public Sector Accounting and Financial Control. Lagos: Financial Training Nigeria, 1996. 
$14 \mid$ Sugimin

Indra Bastian. Audit Sektor Publik. Jakarta: Visi Global Media, 2003.

- - - . Audit Sektor Publik. Jakarta: Salemba Empat, 2007.

K. Oshisami. Government Accounting and Financial Control. Ibadan: Spectrum Books Ltd, 1992.

M. Eze Nwosu. "Value For Money Audit: An Accountability Tool In The Nigeria Public Sector." International Journal of Economics, Commerce and Management Vol. III, no. Issue 6 (Juni 2015): 1537-1544

Mahmudi. Manajemen Kinerja Sektor Publik. Yogyakarta: UPP STIM YKPN, 2007.

Mardiasmo. Akuntansi Sektor Publik. Yogyakarta: ANDI, 2009.

Mardiasmo. "Pengawasan, Pegendalian, Dan Pemeriksaan Kinerja Pemerintah Daerah Dalam Pelaksanaan Otonomi Daerah." Jurnal Bisnis dan Akuntansi 3, no. 2 (2001): 441-456.

Oktarika Ayoe Sandha, dan Indra Bastian. Program Audit Kinerja Berbasis SPKN. Yogyakarta: BPFE UGM, 2008.

Suryo Pratolo. "Value For Money Audit Suatu Instrumen Alternatif untuk Menciptakan Akuntabilitas Publik Pemerintah Daerah." Jurnal Akuntansi dan Investasi 4, no. 1 (2003): 28-43.

R.M. Malan, J. R. Fountain Jr., D.S. Arronsmith, dan R.L. Lockridge II. Performance Auditing in Local Government. Chicago, Illinois: Government Finance Offecers Association., 1984. 